\title{
CONSUMERS' CONSCIOUSNESS AND WILLINGNESS TO PAY FOR FISHERY PRODUCTS WITH ECOLABELS: AN EMPIRICAL STUDY ON UNIVERSITY STUDENTS IN ITALY
}

\author{
Erica Varese ${ }^{1 *}$, Anna Claudia Pellicelli ${ }^{1}$ and Luigi Bollani ${ }^{2}$ \\ ${ }^{1}$ Department of Management, University of Turin, Italy \\ ${ }^{2}$ Department of Social-Economic and Mathematical-Statistical Science, University of \\ Turin, Italy
}

\begin{abstract}
This research concerns ecolabels in the fishery sector and its main objectives are to verify: 1) whether they are recognized and their meaning is known by culturally qualified young consumers and 2) whether it is possible to quantify these consumers' "willingness to pay" (WTP) for fish products bearing ecolabels. Literature review has shown that even though over the years many studies on Corporate Social Responsibility (CSR) labelling were carried out, only few focused exclusively on the fishery sector, analysing the young consumers' point of view. Following literature review, a questionnaire was designed. The measurement scale used in this study was adapted from scales validated in previous papers and double checked against field literature. The final part of this research investigates the sentiment of 411 students of the University of Turin (Italy), employing multivariate statistical methods. The results of this analysis point out that most of the investigated students (39.41\%) on the one hand are very poorly informed about this topic but on the other hand have a medium WTP. Familiarity with ecolabels may improve consumers' sustainability awareness, enabling purchasers to make informed choices. Ecolabels can also support the sea environment avoiding overfishing and the risk of depletion of certain fish stock.
\end{abstract}

Keywords: consumer attitude, willingness to pay (WTP), ecolabels, fishery products, cluster analysis, multivariate analysis

\section{Introduction}

The understanding and consciousness of issues related to Corporate Social Responsibility (CSR), sustainability, and ethical consumption are nowadays becoming increasingly fundamental for producers' supply chains and for consumers (García-Martín et al., 2020). CSR and sustainability are topics which arose nearly 50 years ago and even if the origin and development of their concepts are different, they may reflect complementary aspects. Sustainability was developed after CSR, which may be considered as a way to pursue sustainability (Oliwa, 2021). Companies are therefore requested by stakeholders to attain sustainability by means and strategies related to the triple-bottom line model, which considers all businesses in the perspective of economic, environmental and social aspects (Tate et al., 2010; Petrescu et al., 2020). Furthermore, over the years many authors (Porter and Van Der Linde, 1995; Zadek, 2007; Zeng et al., 2010; Alos-Simo et al., 2020) have stated that business revenue is positively influenced by a cleaner production. 
With reference to ethical consumption, already 20 years ago some scholars (e.g. Shaw and Clarke, 1999; Follows and Jobber, 2000) stated that an ethical and sensitive consumer feels a direct link between what is consumed and the environmental/social implications of his/her consumption. Since the 1960s, per capita global fishery and aquaculture (F\&A) consumption has doubled (FAO, 2018), mostly because health benefits of fish consumption were revealed (Verbeke et al., 2007). These products, in fact, offer more benefits than harm for a variety of health outcomes: it has been stated that every 20 grams per day (approximately one serving/week) increment «could decrease by $2 \%-7 \%$ the risk of coronary heart disease mortality, cardiovascular disease mortality, all-cause mortality, stroke, myocardial infarction, acute coronary syndrome, heart failure, gastrointestinal cancer, metabolic syndrome, dementia and Alzheimer's disease. Beneficial associations were also found for cancers, atopic, musculoskeletal, gastrointestinal and ophthalmologic outcomes» (Li et al., 2020).

F\&A products also provide high quality proteins, they have a low-fat content and, at the same time, they are characterized by many micro-nutrients such as vitamins and minerals (Yaktine and Nesheim, 2007). Eating fish also depends on other factors such as i) country; ii) socio-demographic characteristics; iii) cultural traditions, which have been changing over time (Almeida et al., 2014); iv) marketing, communication and information provisioning (Jacobs et al., 2018). The above-mentioned demand growth confirms the significant and increasing role of $\mathrm{F} \& \mathrm{~A}$ in providing healthy food for human consumption and in the rapid development of their international trade. Fish and fish products are nowadays among the most merchandised commodities in the world (totally estimated USD 145 billion in 2017) and fisheries have to be properly managed to avoid overfishing (Verbeke et al., 2007), which is considered biologically unsustainable. (FAO, 2020). Maxwell et al. (2015) provide an interesting definition of "dynamic ocean management" which implies a sustainable approach: this management fluctuates in space and time and acts upon the instable «nature of the ocean and its users», built «on the integration of new biological, oceanographic, social and/or economic data in near real-time». The last report edited by FAO (2020) on "The State of World F\&A" reveals that «total fish production (excluding aquatic plants) is expected to expand from 179 million tonnes in 2018 to 204 million tonnes in 2030». This production, in per capita terms, reveals that world fish consumption is projected to touch $\mathrm{kg} 21.5$ in 2030, up from $\mathrm{kg} 20.5$ in 2018. According to Assoittica Italia (Associazione Nazionale delle Aziende Ittiche - Italian National Association of Fish Farms), fishery products represent an important portion of the annual diet intake: Italians consume about $\mathrm{kg} 28$ a year per capita, the highest level of consumption in the European Union (EU). (ANSA, 2018). In the past, consumers were incapable to make conscious choices related to F\&A products, as it was quite difficult to recognize whence the fish originated, how it was caught (Jaffry et al., 2004) or the production methods. In order to enable consumers to enjoy safe use of food and to make informed choices, Regulation (EU) $n^{\circ} 1169 / 2011$ on the provision of Food Information to Consumers (FIC) and Regulation (EU) $n^{\circ} 1379 / 2013$ on the Common Organization of the Markets in F\&A products (CMO) have provided accurate and wide-ranging rules on, inter alia, the method of production and the origin of products. These provisions shall be indicated in labelling. The general objective of FIC is to accomplish free movement of legally produced and marketed food in the EU and, at the same time, a high level of consumer health protection. CMO, without prejudice to FIC, establishes that F\&A products listed in points (a), (b), (c) and (e) of Annex I (in short, all unprocessed and some processed products - e.g. salted, smoked products, cooked shrimps in their shells) which are marketed within the EU, regardless of their origin or their marketing method, may be offered for sale to the final consumer or to a large retailer only if appropriate marking or labelling includes the required indications. Article 
35 of the CMO Regulation specifies how the production method, the catch area/farmed area and the category of fishing gear may be indicated in prepacked and non-prepacked F\&A products. The production method, for example, must be displayed using the following designations: "caught ..."; or "caught in freshwater ..."; or "farmed ...". Mixed products of the same species and different production methods must display the method of production for each batch. According to the FIC regulation, food business operators may provide food information even voluntarily but, in any case, the latter shall not misinform the purchaser, shall not be ambiguous or confusing and, where appropriate, shall be founded on relevant scientific records. Voluntary food information shall not be shown to the detriment of the space available for mandatory food information.

Nowadays, ecolabels have become very widespread for a wide range of products and, at international level, up to 455 voluntary ecolabel schemes can be found in the markets of 199 countries, referring to 25 food and non-food industry sectors (Ecolabel Index, 2021). Such a high number of ecolabels can trigger the effect that consumers do not understand and perceive them (Taufique et al., 2019) and, therefore, that they are not conscious of their differences (Carrero and Valor, 2012; Eldesouky et al., 2020). If this happens, it is very difficult and sometimes impossible for them to make aware choices (OECD, 2009, D’Souza et al., 2007, Annunziata et al., 2011). It has to be said that some of these labels can also look similar (Ecolabel and ISO 14001) even if the standard is very different (Fliess et al., 2007). However, if consumers have the capability to distinguish these ecolabels from and among the others and to understand their correct meaning, they can be driven towards sustainable products (Asioli et al., 2020) even if this decision is obviously induced also by other drivers such as familiarity, price of the product and willingness to pay for it as a percentage of the base price (WTP), promotion, traceability (Katt and Meixner, 2020), packaging and brand (Grunert and Aachmann, 2016; Schäufele and Hamm, 2017). With reference to the above mentioned 455 voluntary ecolabels, only 6 are related to the fishery sector and just 3 are found in the Italian market (Table 1).

Table 1: Ecolabels for fishery products: logo and countries where they can be found

\begin{tabular}{ll}
\hline Logo & Countries \\
\hline Dolphin safe / Dolphin & American Samoa, Argentina, Australia, Austria, Belgium, Brazil, Canada, Colombia, \\
friendly & Costa Rica, Ecuador, Egypt, France, Germany, Indonesia, Ireland, Israel, Italy, Japan, \\
Liechtenstein, Luxembourg, Maldives, Mauritania, Mauritius, Monaco, Netherlands, \\
Nicaragua, Norway, Panama, Papua New Guinea, Peru, Philippines, Poland, Portugal, \\
Puerto Rico, Romania, Russian Federation, Samoa, Seychelles, South Africa, Spain, \\
Sweden, Switzerland, Thailand, Turkey, United Kingdom, United States, United States \\
Minor Outlying Islands, Venezuela.
\end{tabular}

Friend of the Sea

Germany, Italy, Spain, Switzerland, United Kingdom.

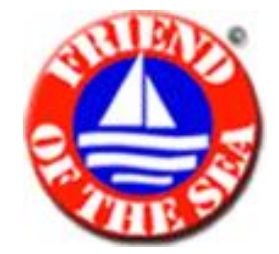




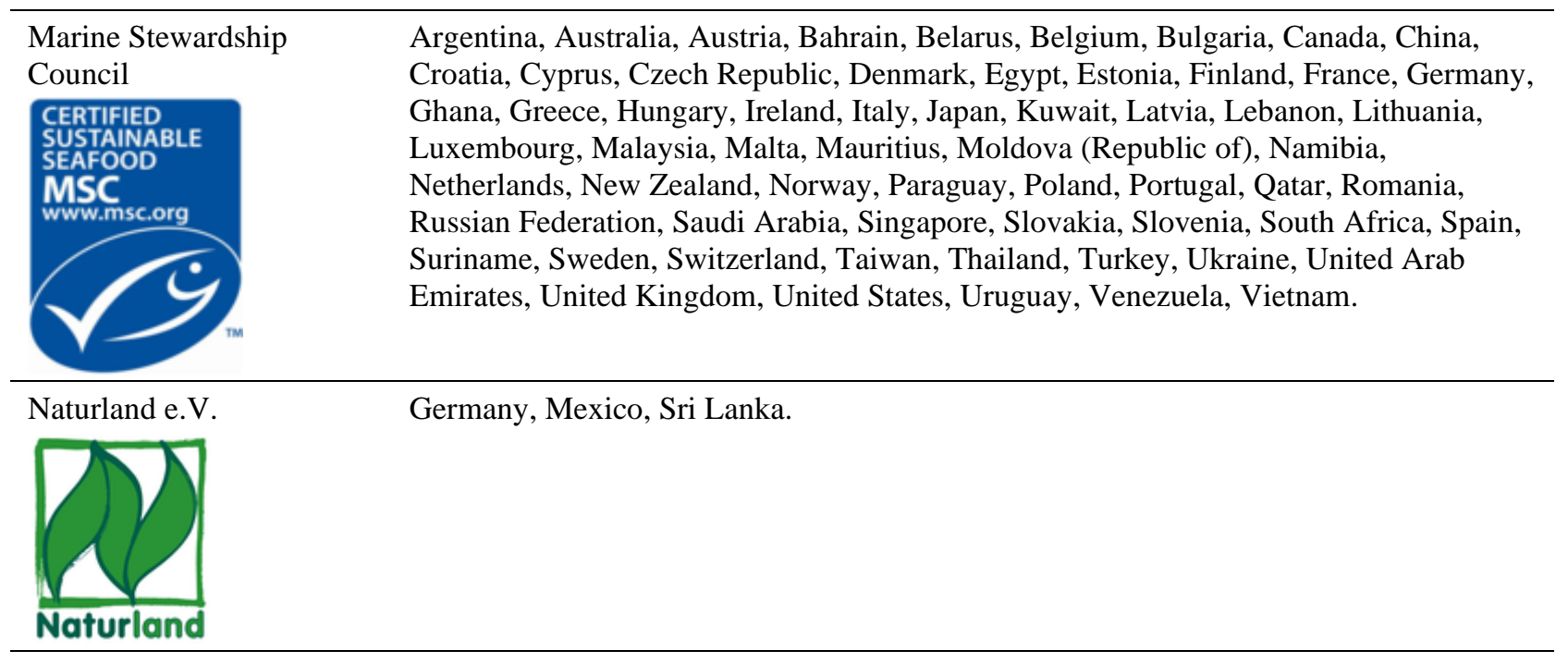

Salmon-Safe

United States.

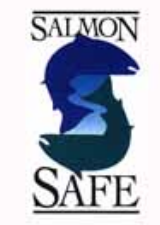

SeaChoice

Canada.

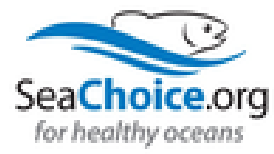

Source: Adapted by the authors from Ecolabelindex (2021).

This study analyses only ecolabels available in the Italian market. These labels may be found by consumers on very popular fish products such as, for example, tuna, cod and salmon. The prices of these products are obviously related to various aspects such as type of fish, net quantity of the food, brand, sort of packaging, kind and amount of liquid medium in which eventually the solid food is presented, distribution channel, special offers etc. Just to give an idea of the price, Table 2 shows the different prices of 80 grams and 160 grams cans of tuna (with and without the Dolphin Safe/Dolphin Friendly logo) sold at a very popular supermarket in Turin, which trades also on line (prices on line are the same as those in the supermarket). Products on special offer have not been considered.

Table 2: prices of cans of tuna with and without the Dolphin Safe/Dolphin Friendly logo (the items are presented by rising prices per kind of liquid medium)

\begin{tabular}{llllll}
\hline Brand & $\begin{array}{l}\text { Tuna in ... } \\
\text { liquid medium }\end{array}$ & $\mathrm{N}^{\circ}$ cansxg & $\begin{array}{l}\text { Drained weight } \\
\text { grams total amount } \\
\left(\mathrm{N}^{\circ} \text { cansxg }\right)\end{array}$ & $\begin{array}{l}\text { Price } \\
\text { euro/kg }\end{array}$ \\
\hline Brand 2 & In olive oil & $3 \times 80 \mathrm{~g}$ & $\mathrm{~g} 156(3 \times 52 \mathrm{~g})$ & 9.63 & No \\
\hline Private label & In olive oil & $4 \times 80 \mathrm{~g}$ & $\mathrm{~g} 208(4 \times 52 \mathrm{~g})$ & 10.91 & No \\
\hline Brand 1 & In olive oil & $4 \times 80 \mathrm{~g}$ & $\mathrm{~g} 208(4 \times 52 \mathrm{~g})$ & 17.47 & Yes
\end{tabular}




\begin{tabular}{|c|c|c|c|c|c|}
\hline Brand 5 & In brine & $3 \times 80 g$ & g $158(3 \times 56 g)$ & 10.78 & Yes \\
\hline Private label & In brine & $3 \times 80 \mathrm{~g}$ & g $168(3 \times 56 g)$ & 15.42 & No \\
\hline Brand 3 & In brine & $4 \times 80 g$ & g $224(4 \times 56 g)$ & 17.80 & Yes \\
\hline Brand 2 & In extra virgin olive oil & $4 \times 80 g$ & g $208(4 \times 52 g)$ & 18.44 & No \\
\hline Brand 1 & In extra virgin olive oil & $4 \times 80 g$ & g $208(4 \times 52 g)$ & 21.67 & Yes \\
\hline Brand 4 & In extra virgin olive oil & $2 \times 80 g$ & g $104(2 \times 52 g)$ & 31.14 & Yes \\
\hline Private label & In olive oil & $4 \times 160 g$ & g $416(4 \times 104)$ & 10.93 & No \\
\hline Brand 1 & In olive oil & $2 \times 160 g$ & g $208(2 \times 104 g)$ & 17.16 & Yes \\
\hline Brand 5 & In olive oil & $3 \times 160 g$ & g $312(3 \times 104 g)$ & 21.70 & Yes \\
\hline
\end{tabular}

Source: Esselunga a casa (2021).

The price for this kind of fish product, at the considered supermarket, is between 9.63 euro/kilo ( 3 cans of 80 grams of tuna in olive oil without the ecolabel logo) and 31.14 euro/kilo ( 2 cans of 80 grams of tuna in extra virgin olive oil with the Dolphin Safe logo). Further consideration about the data provided in this table will be presented in the discussion and conclusions section.

In Italy, 0.3 million tonnes of fish (including molluscs and crustaceans) were produced in 2018, with a corresponding value of USD 1658.4 million. 68\% of this value come from fisheries (that is, capture of wild resources) and 32\% from aquaculture. Italy is a net importer of fish and fish products. Between 2008 and 2018, the quantity produced decreased by $10 \%$, while its value decreased by $15 \%$. Exports decreased by a total of $1 \%$, while imports increased by $16 \%$ (OECD, 2021). As stated above (ANSA, 2018), Italians consume about $\mathrm{kg} 28$ of fish per capita a year; 28 percent of respondents taking part in a recent survey (Ipsos, 2019) stated that it is very important to them that the fish they consume is not on a list of species at risk of disappearing. Just over half of the participants said this was somewhat important to them.

This study was carried out in the above-mentioned Italian context. It aims at presenting the second part of an empirical study on ecolabels in the fishery sector, carried out at the University of Turin (Italy), among University students (the first part of the research is at present in press, Varese et al., 2022).

\section{Literature review}

CSR labels declare that a product has achieved or is about to attain a certain level of social or environmental performance. Thanks to these labels, credence attributes which are impossible to evaluate before consumption are turned into search ones, which can be assessed prior to purchase (Carrero and Valor, 2012). It is possible to classify CSR labels into three main groups. The first one may relate to a wide variety of aspects, e.g. specific products such as seafood (Jaffry et al., 2004; Honkanen and Young, 2015), meat (Van Loo et al., 2014), coffee (Van Loo et al., 2015; Vlaeminck et al., 2016), and wine (Schäufele and Hamm, 2017); geographic indication and organic production (Zander et al., 2015; Drexler et al., 2017; Bazzani et al., 2017); social responsibility labels, e.g. fair trade (Panico et al., 2014); animal well-being (Honkanen and Ottar Olsen, 2009; Velarde et al., 2015; Grunert et al., 2018); and climate friendly food consumption (Feucht and Zander, 2018; Leach et al., 2016). In brief, according to Hartlieb and Jones (2009), following the topic criterion, CSR labels may 
be classified as "planet" (environmental), "people" (social justice) or "animals" (animal well-being). The second group consists in three different types of voluntary environmental labels, identified by the International Organisation for Standardization (ISO). Type I labels are centred on a pass-fail multicriteria approach designed to indicate the overall environmental performance of a product which will not be eligible for the label if even one of the criteria is not satisfied (e.g. eco-labels which are third-party verified). Type II labels are self-declared, generally communicated by means of a claim (e.g. "made from $\mathrm{x} \%$ recycled material") made by business operators who state the environmental quality of their goods. These labels appear in a written and/or figurative (symbolic) form and are not verified by a third party. These declarations should not be ambiguous, misleading or vague, and should be demonstrable. Type III labels include a variety of information on different aspects of the product supply chain; they are performance-based, and they are verified by a third party (e.g. Fairtrade International) (D'Souza et al., 2007; Carrero and Valor, 2012). Finally, the third group refers to the awarding competent body, e.g. self-declared labels, industry body, non-governmental organization (Zadek et al., 1998), public authorities and multi-stakeholder organisations. Scholars have analysed all or some of the above-mentioned CSR labels one by one or jointly (D'Souza et al., 2006; Annunziata and Scarpato, 2014; Grunert et al., 2014; Sidali et al., 2016; Hoek et al., 2017; Asioli et al., 2017).

Sustainable management may require consumers to be willing to pay a premium price for products bearing CSR attributes (for the fishery sector see: Smith et al., 2010). When this occurs, some authors claim that consumers are not ready to spend more money for these products (Padel and Foster, 2005; Vermeir and Verbeke, 2006; Grunert et al., 2014; Vlaeminck et al., 2016), while others underline the willingness of consumers to pay a premium price (Laroche et al., 2001; Loureiro and Lotale, 2005; Sammer and Wüstenhagen, 2006; D'Souza et al., 2007; Kotler, 2011; Tully et al., 2014). Focusing on the fishery sector, over the years, some scholars (Teisl et al., 2002; Roheim et al., 2007; Roheim et al., 2011; Asche and Guillen, 2012; Hammarlund, 2015) have concentrated their research on fishery attributes (e.g. green sustainability, country of origin, fishing gear option, and fishing technique).

This empirical study aims at verifying whether the above-mentioned Italian fishery ecolabels are recognized and their meaning is known by culturally qualified young consumers. Its goal is also to ascertain whether it is possible to quantify these consumers' WTP for fish products bearing these attributes.

To the authors' evidence, researches which investigate the attitudes of young consumers towards ecolabels are limited (Vermeir and Verbeke, 2008; Mäkiniemi et al., 2011; Lee, 2014; Li et al., 2015; Savelli et al., 2017; Sidiropoulos, 2018; Bollani et al., 2017; Bollani et al., 2018) and a few have studied only fishery ecolabels (e.g., Varese et al., 2022 in press). The authors also presume that this research will contribute to filling a gap in literature because, beside investigating the perception by young people, it explores the WTP for fishery products characterised by ecolabels. Companies will be confronted with CSR strategies more and more, and since University students will be the consumers of the future, the information inferable from this study can be useful for them.

\section{Aims of the study}

As stated above, the objective of this study is to test the comprehension of fishery ecolabels by University students and to verify the possibility of quantifying their WTP as a percentage of the base 
price for food products bearing the related ecolabels. With reference to the classification of CSR labels proposed in the literature review, the selected fishery ecolabels deal with specific products (fish) and refer to animal well-being and environmental protection. They belong to Type III ISO classification and are acknowledged by international organisations.

The meaning of these 3 logos and the differences among them are briefly described hereafter. Dolphin safe/Dolphin friendly (black and white logo) is awarded by the Earth Island Institute which monitors tuna companies worldwide to ensure tuna fish are caught without any dolphin mortality and by protecting the marine ecosystem. Friend of the Sea (red, blue and white logo) aims to improve the global sustainability of seafood by developing international certification schemes for sustainable fisheries and aquaculture products. The Marine Stewardship Council (blue-and-white logo) is a mark that sets standards for sustainable fishing, certifying that fisheries minimise their impacts on the whole marine environment in order to ensure healthy, thriving oceans for the future.

This research investigates University students because they present similar characteristics (a high school diploma and the same age bracket), and as they have probably attended commodity science, social science, and/or economics classes they may have some awareness of the concept of sustainability, which is a key aspect for the aim of this research. According to Vermeir and Verbeke (2008), young people attending University are in a crucial step of the development of their personal identity, which also includes beliefs and values. If sustainability is a relevant concept for them, they will probably take this consciousness into their older age and therefore they will encourage policy makers to improve food consumption habits within the population.

In order to pursuit the aim of this study, two research questions were asked:

Q1) Are University culturally qualified students conscious of the meaning of ecolabels related to the fishery sector?

Q2) Is it possible to quantify their WTP for fishery products with QMs?

In order to answer these questions, first of all an in-depth literature analysis on ecolabels was performed. Thereafter, an anonymous questionnaire was structured, also taking into consideration previous relevant research emerged from the literature analysis (D'Souza et al., 2006; Grunert et al., 2014; Sidali et al., 2016; Hoek et al., 2017; Cerri et al., 2018). The study investigated both Bachelor and Master students, and considered three fishery ecolabels: Dolphin Safe; Friend of the Sea; and Marine Stewardship Council (Table 1). These ecolabels were drawn from the Ecolabel Index directory, considering only the ones available in the Italian market.

In order to check the validity of the questionnaire, so as to discover any imprecision and any structural limitation (Clonan et al., 2010; Vecchio and Annunziata, 2013), a preliminary version of the survey was submitted to about 20 students of the University of Turin. After a few amendments, a definitive version was defined and submitted through "Computer-assisted personal interviewing" (CAPI); a trained interviewer was always available to help and guide respondents. The three above mentioned ecolabels were verified for knowledge ("Have you ever seen these ecolabels?") and respondents were asked to rate their familiarity with each ecolabel on a 7-point Likert scale (Likert, 1932) with endpoints $1=$ "Never" and 7="Always". 


\section{Statistical methods}

Multivariate statistical techniques were used to investigate the responses. As they can be traced back to both quantitative (Likert scales) and qualitative variables, two different techniques were used to reduce dimensionality and explore the relationships among them. Principal Component Analysis (PCA) was employed to summarize the responses proposed in the Likert scales, and Multiple Correspondence Analysis (MCA) to show the relationships among qualitative variables. Moreover, Hierarchical Cluster Analysis (HCA) was used to group respondents; it was computed using the main PCA or MCA dimensions as inputs, and for this aim a PCA-HCA process or a MCA-HCA process were used.

In particular, a first synthesis of quantitative variables was carried out through the PCA-HCA process, dividing respondents into levels of a new qualitative variable; it was then added to the other qualitative variables available in the questionnaire to produce the input of an MCA-HCA process. Finally, the groups of respondents, thus constituted using all information conveyed by the responses, became the object of study regarding their opinions and behaviours.

R software, FactoMineR (Escofier and Pagès, 2005) and CA (Greenacre, 2007) packages were used for the analyses.

\section{Results}

The results refer to 411 persons who are $59.37 \%$ male and $40.63 \%$ female. As to age, they are divided into the following groups: 18-20 (65.69\%), 21-23 (28.95\%), and >23 years-old (5.35\%).

A preliminary synthesis of the variables expressed in Likert scales, through the PCA-HCA process, produced the qualitative variable named "Environmental and economic features" in Table 3. Its levels are identified in the following clusters: the first cluster (24.82\% of the sample) considers brand very important, but has low confidence in the seller; the second one $(22 \%)$ judges both confidence in the seller and information acquired through labels very significant, and on the other hand gives low importance to product safety and to ethical and social aspects; the third and final cluster $(52.80 \%)$ gives average importance to ethical and social aspects, but low significance to brand and information acquired through labels.

Table 3 shows the complete set of qualitative variables used in this research and considered in the MCA analysis.

Table 3: Variables and items considered in multivariate analyses

\begin{tabular}{lll}
\hline Variables & Items & Descriptions \\
\hline \multirow{2}{*}{ Cruelty free information check } & Anim.welf_more & Attention to animal welfare \\
& Anim.welf_less & Indifference to animal welfare \\
\hline \multirow{2}{*}{ Label reading frequency } & Read_more & $\begin{array}{l}\text { High label reading frequency } \\
\text { Low label reading frequency }\end{array}$ \\
\hline \multirow{2}{*}{ Sustainable fishery symbol } & S.fish.Yes & Symbol recognized as seen \\
& S.fish.No & Symbol recognized as not seen
\end{tabular}




\begin{tabular}{lll} 
& S.fish.Idk & Symbol not remembered \\
\multirow{2}{*}{$\begin{array}{l}\text { Sustainable tuna fishing } \\
\text { symbol }\end{array}$} & S.tuna.Yes & Symbol recognized as seen \\
& S.tuna.No & Symbol recognized as not seen \\
& S.tuna.Idk & Symbol not remembered \\
\hline \multirow{3}{*}{ Ocean protection symbol } & S.ocean.Yes & Symbol recognized as seen \\
& S.ocean.No & Symbol recognized as not seen \\
& S.ocean.Idk & Symbol not remembered \\
\hline \multirow{2}{*}{ Willingness to pay (WTP) - } & Fish_0-5 & From 0 to 5\% more \\
Fish & Fish_6-15 & From 6 to 15\% more \\
& Fish_over15 & Over 15\% more \\
\hline \multirow{2}{*}{ Willingness to pay (WTP) - } & Tuna_0-5 & From 0 to 5\% more \\
Tuna & Tuna_6-15 & From 6 to 15\% more \\
& Tuna_over15 & Over 15\% more \\
\hline \multirow{2}{*}{ Willingness to pay (WTP) - } & Ocean_0-5 & From 0 to 5\% more \\
Ocean & Ocean_6-15 & From 6 to 15\% more \\
& Ocean_over15 & Over 15\% more \\
\hline \multirow{2}{*}{ Environmental and economic } & Val_ES & High value given to ethics and safety \\
features & Val_EB & High value given to ethics and brand \\
& Val_TI & High value given to trust and information \\
\hline \multirow{2}{*}{ Gender } & Female & Female \\
& Male & Male \\
\hline \multirow{2}{*}{ Age } & $18-20$ & $18-20$ \\
& $21-23$ & $21-23$ \\
\hline & $>23$ & $>23$ \\
\hline
\end{tabular}

Graph 1 represents the output of the MCA.

As can be perceived from Graph 1, the upper part of the map shows - far from the others - the respondents who do not remember to have seen the symbols considered in the analysis, but even those who do not know the correct meaning associated with QMs. Following the first dimension, starting from the left side, low WTP levels (0-5\% more) can be found for the presence of each symbol printed on the label; moving to the right side of the graph, a medium WTP can be observed (6-15\% more) for all QMs; and the elements on the far-right side mark a high WTP (>15\%). Following the second dimension, the respondents collected in the group sensitive to ethics and brand importance (Val_EB) are placed at the bottom of the chart. Moving from the bottom up, the group sensitive to ethics and safety (Val_ES) can be found first, while the group sensitive to trust and information (Val_TI) is shown higher in the graph. On the same path, those who did not recognize the three assessed QMs (any of them) are placed in the lower part of the chart, while those who recognized them are positioned higher in the graph. Female respondents are placed more to the right/top side of the graph, due to their greater WTP for the presence of each symbol printed on the label (right side) and to a greater ability in recognizing QMs and confidence in the seller (higher, on the side). In the same way, those who read more information on labels and those who are more sensitive to animal welfare are placed in a far-right and higher region. As far as respondents' age is concerned, 21-23 and 18-20year-olds show similar behaviour, while the smaller share of $>23$ years olds seems to be slightly more focused on sustainable practices. 


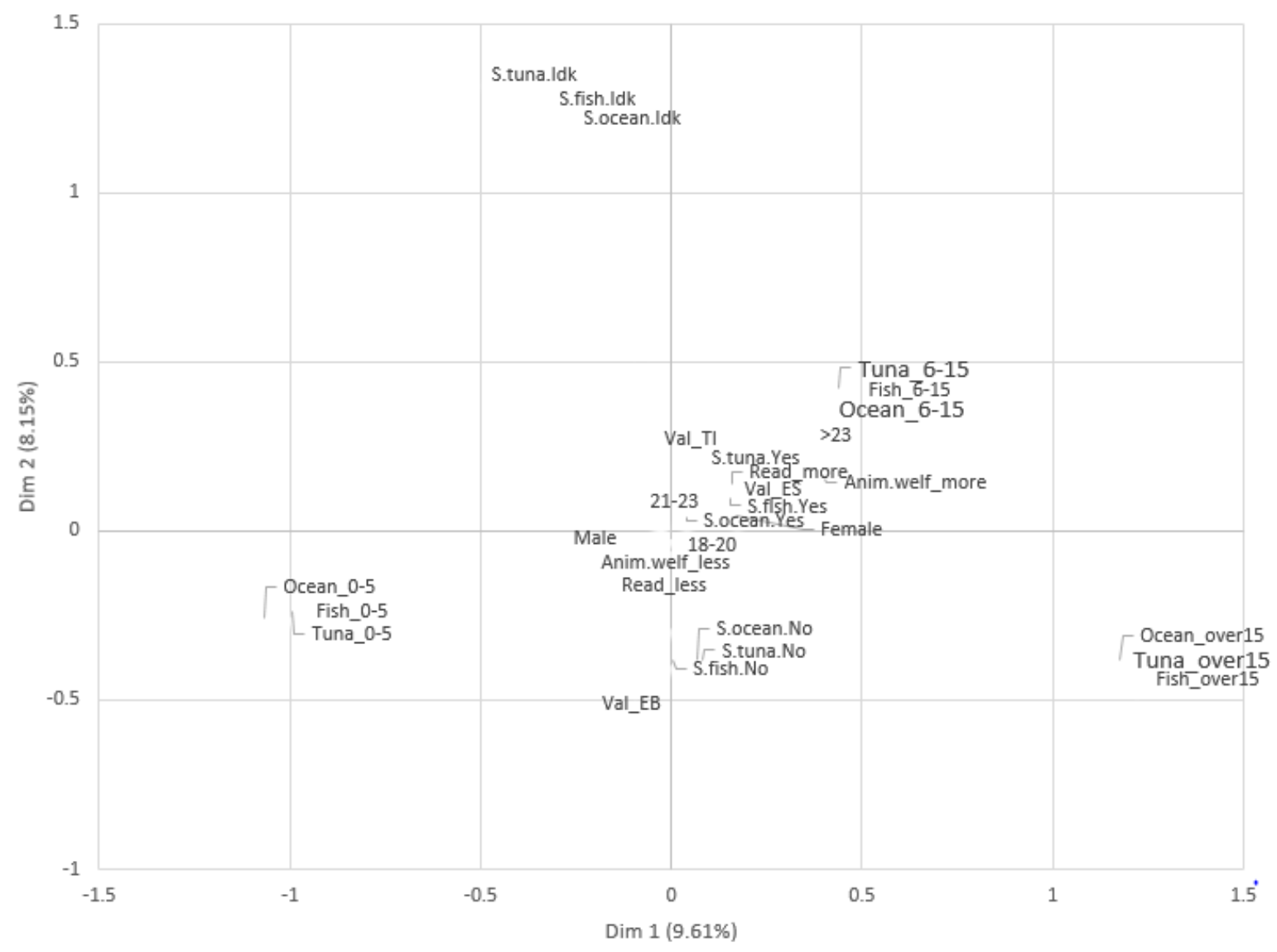

Graph 1: Relationships among all the items considered (MCA)

N.B. By applying Greenacre's re-evaluation (2007) of the inertia referred to the first two dimensions in both Graphs 1 and 2 (in consideration of the artificial inflation of the inertia produced by the MCA coding scheme), $27.64 \%$ was obtained for the first dimension and $15.70 \%$ for the second.

Finally, HCA was performed, based on the main dimensions of the MCA, obtaining four clusters of University students which are represented in Graph 2.

The first cluster (including $18.73 \%$ of respondents) is characterized by a very low WTP (0-5\%): it groups male respondents - more than in other cases - who are not interested in reading and checking product labels. The second cluster $(39.41 \%)$ stands out because it is very uninformed about all questions asked throughout the questionnaire; it consists in 21-23 and >23 years old respondents older than in the other cases - and it is characterized by a medium WTP (6-15\%). The students of the third cluster (12.40\%) show a medium tendency regarding their WTP, and they do not recognise QMs. The remaining respondents on the left side of the graph (29.44\%) have a greater WTP than the others (more than 15\%) and they are very interested in ocean protection. 


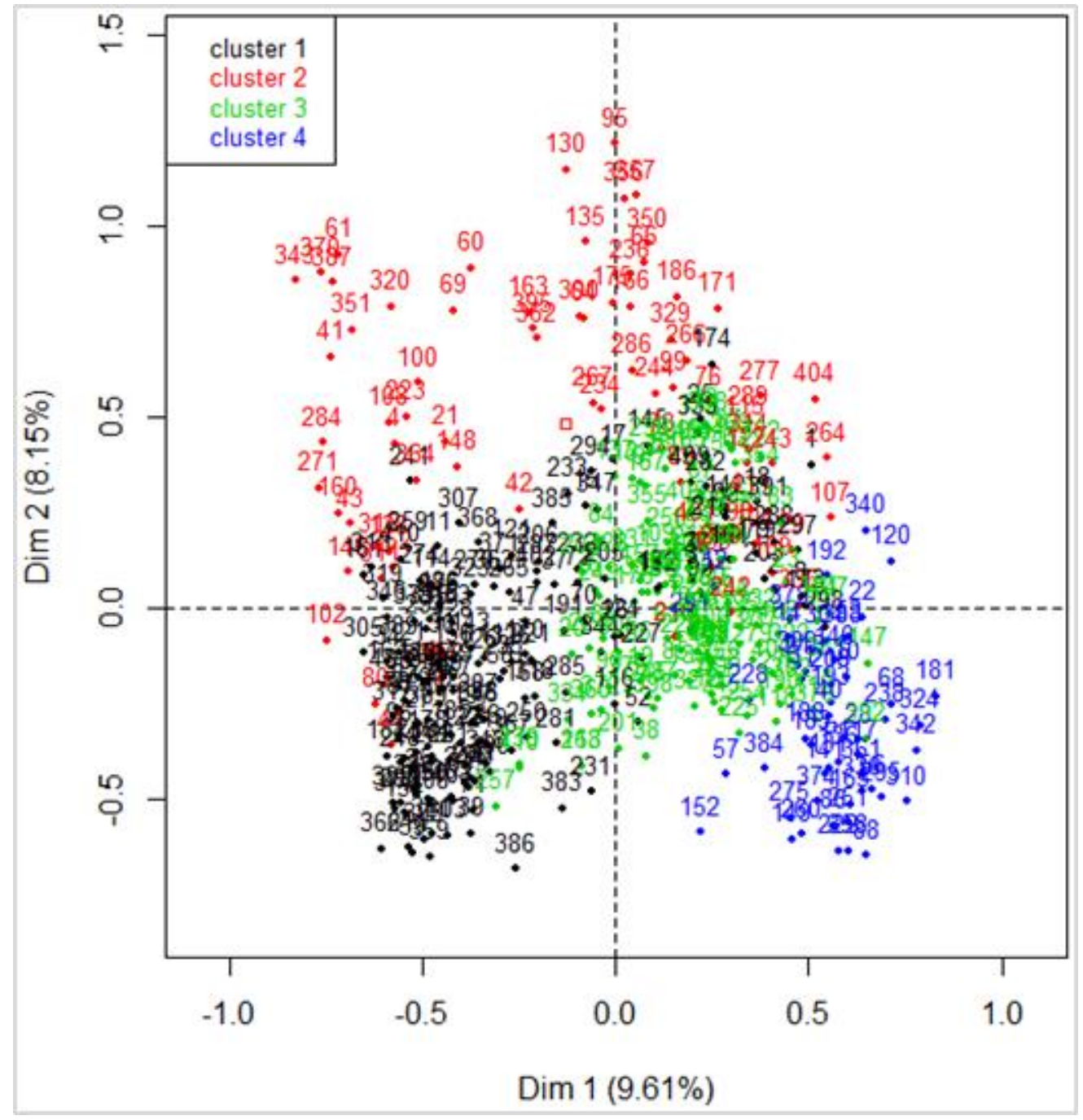

Graph 2: Cluster of individuals with respect to the characteristics obtained through the MCA

\section{Discussion and Conclusions}

According to Thilsted et al. (2016) the fish intake has increased in the last decades but the recommended per-capita fish is not generally reached. It has been demonstrated (FAO, 2021) that fish consumption offers human beings unique health and nutritional benefits (high value proteins, source of micronutrients and long chain omega-3 fatty acids) and fish and fishery products are considered key elements in a healthy diet.

CSR plans and policies which involve ecolabels have been implemented over the years by many companies worldwide because there is a very high demand for them from both consumers and markets (Carrero and Valor, 2012).

Even if the above-mentioned fishery ecolabels have been chosen by a wide range of fisheries, it has to be pointed out that some critical aspects regarding these certifications can be identified. These limits are basically due to the cost of the certification which allows fisheries to display the ecolabel and therefore to assure consumers of the respect of the specific standard. These costs can therefore be 
difficult to bear by smaller fisheries which would thus not be able to apply for such certification schemes (Hadjimichael and Hegland, 2016). Furthermore, according to Mori Junior et al. (2016), in some countries the absence of such certifications also acts as a trade barrier. Another constraint of these three fishery ecolabels is related to the elements taken into consideration for achieving the certification, which, in the absence of an appropriate regulation on ethical concerns on the production side, may contribute to a risk of unethical behaviour by food manufacturers (Del Giudice et al., 2018).

It is in this context that this research has been carried out, in order to answer the two research questions concerned with 1) how University students perceive fishery ecolabels and 2) the percentage of their WTP.

Authors are aware that the chosen sample is a culturally qualified one and does not represent all young consumers, but they have decided that for the aim of this research it seems crucial to consider young people who may have some knowledge of the notion of sustainability. Young people who do not attend University may have learnt CSR and sustainability issues from outside the classroom as well; however, in order to verify their level of knowledge, authors should have made a previous screening to certify their awareness of these topics before submitting the questionnaire. University students, on the other hand, should have this knowledge.

Even if the examined sample focuses on young students, authors believe that this does not interfere with their possibility to purchase products with ecolabels because, as shown in Table 2, the prices of a can of tuna are sometimes very similar for products with or without ecolabel. It may even happen that a branded can of tuna in brine with CSR ecolabel is cheaper (Brand 5, euro/kg 10.78) than a private label one without the CSR logo (Private label, euro/kg 15.42).

The sustainability concept is generally recognised by consumers as relevant, but they do not always have the appropriate skills to recognise the implications and value of ecolabels and, even if they may be able to perceive the meaning of the sign, they may not have the WTP for it.

The results of this research identify four categories of respondents. The first one (including $18.73 \%$ of respondents) is characterized by a very low WTP (0-5\%); it groups male respondents, who are not interested in reading and checking the presence of ecolabels. The second one (39.41\%) stands out because it is very uninformed: it mainly consists in 21-23 and >23-year-olds and it is characterized by a medium WTP $(6-15 \%)$. The third category $(12.40 \%)$ shows a medium tendency regarding WTP, without recognition of ecolabels. The last category $(29.44 \%)$ is willing to pay more than the others (over $15 \%$ more) and is very interested in ocean protection. The findings of a recent paper published by Maesano et al. (2020) confirm the positive trend above mentioned in this research, as overall consumers have demonstrated a confident perception about sustainable fish products and show a WTP a premium price for sustainability aspects.

Since most of the investigated students (39.41\%) are on the one hand very poorly informed about this topic, but on the other hand have a medium WTP, these findings may encourage all fishery stakeholders to stimulate young consumers with better information and promotion of these ecolabels, so as to increase consumers' sustainability consciousness for greater awareness in purchases. 
Future studies including aquaculture ecolabels, focusing on university students also from other Italian and European Universities and only on consumers eating fish (wild or farmed) seem necessary.

\section{Declaration of Interest Statement}

The authors declare that they have no conflicts of interests.

\section{References}

Almeida, C., Altintzoglou, T., Cabral, H., \& Vaz, S. (2015). Does seafood knowledge relate to more sustainable consumption? British Food Journal, 117(2), 894-914. doi: 10.1108/BFJ-04-2014-0156.

Alos-Simo, L., Verdu-Jover, A.J., \& Gomez-Gras, J.M. (2020). Does activity sector matter for the relationship between eco-innovation and performance? Implications for cleaner production. Journal of Cleaner Production, 263, 121544. doi: 10.1016/j.jclepro.2020.121544.

Annunziata, A., \& Scarpato, D. (2014). Factors affecting consumer attitudes towards food products with sustainable attributes. Agricultural Economics/Zemedelska Ekonomika, 60(8), 353-363.

Annunziata, A., Ianuario, S., \& Pascale, P. (2011). Consumers' attitudes toward labelling of ethical products: The case of organic and Fair Trade products. Journal of Food Products Marketing, 17(5), 518-535. doi: 10.1080/10454446.2011.618790.

ANSA (2018). Italia prima in Ue per consumi di pesce, $28 \mathrm{~kg}$ a testa $(+2 \%)$. Available at: http://www.ansa.it/canale_terraegusto/notizie/dal_mare/2018/11/21/italia-prima-in-ue-per-consumidi-pesce-28-kg-a-testa-2_a8d23769-4336-4488-a0ae-1c7b9c66e6b7.html (accessed 18 May 2021).

Asche, F., \&Guillen, J. (2012). The importance of fishing method, gear and origin: the Spanish hake market. Marine Policy, 36, 365-369. doi: 10.1016/j.marpol.2011.07.005.

Asioli, D., Aschemann-Witzel, J., \& Nayga Jr, R.M. (2020). Sustainability-related food labels. Annual Review of Resource Economics, 12, 171-185. doi: 10.1146/annurev-resource-100518-094103.

Asioli, D., Aschemann-Witzel, J., Caputo, V., Vecchio, R., Annunziata, A., Næs, T., \& Varela, P. (2017). Making sense of the "clean label" trends: A review of consumer food choice behavior and discussion of industry implications. Food Research International, 99, 58-71. doi: 10.1016/j.foodres.2017.07.022.

Bazzani, C., Caputo, V., Nayga Jr, R.M., \&Canavari, M. (2017). Revisiting consumers' valuation for local versus organic food using a non-hypothetical choice experiment: Does personality matter? Food Quality and Preference, 62, 144-154. doi: 10.1016/j.foodqual.2017.06.019.

Bollani, L., Peira, G., Varese, E., Nesi, E., Pairotti, M.B., \& Bonadonna, A. (2017). Labelling and sustainability in the green food economy: Perception among millennials with a good cultural background. Rivista di Studi sulla Sostenibilità, 2, 83-101. doi: 10.3280/RISS2017-002007.

Bollani, L., Varese, E., \& Pellicelli, A.C. (2018). Attitude towards food labelling bearing sustainable quality marks: an empirical evidence. In: Proceedings $24^{\text {th }}$ International Sustainable Development Research Society Conference "Actions for a sustainable world. From theory to practice". University of Messina, Messina (Italy), June, 13-15; 606-613.

Carrero, I., \& Valor, C. (2012). CSR-labelled products in retailers' assortment: A comparative study of British and Spanish retailers. International Journal of Retail \& Distribution Management, 40(8), 629-652. doi: 10.1108/09590551211245425.

Cerri, J., Testa, F., \& Rizzi, F. (2018). The more I care, the less I will listen to you: How information, environmental concern and ethical production influence consumers' attitudes and the purchasing of sustainable products. Journal of Cleaner Production, 175, 343-353. doi: 10.1016/j.jclepro.2017.12.054. 
Clonan, A., Holdsworth, M., Swift, J., \& Wilson, R. (2010). UK Consumers Priorities for Sustainable Food Purchases. 84 ${ }^{\text {th }}$ Annual Conference of the Agricultural Economics Society, Edinburgh 29-31 March 2010.

D’Souza, C., Taghian, M., \& Lamb, P. (2006). An empirical study on the influence of environmental labels on consumers. Corporate Communications: An International Journal, 11(2), 162-173. doi: $10.1108 / 13563280610661697$.

D’Souza, C., Taghian, M., Lamb, P., \& Peritatko, R. (2007). Green decisions: demographics and consumer understanding of environmental labels". International Journal of Consumer Studies, 31(4), 371-6. doi: 10.1111/j.1470-6431.2006.00567.x.

Del Giudice, T., Stranieri, S., Caracciolo, F., Ricci, E.C., Cembalo, L., Banterle, A., \& Cicia, G. (2018). Corporate Social Responsibility certifications influence consumer preferences and seafood market price. Journal of Cleaner Production, 178, 526-533. doi: 10.1016/j.jclepro.2017.12.276.

Drexler, D., Fiala, J., Havlíčková, A., Potůčková, A., \& Souček, M. (2017). The effect of organic food labels on consumer attention. Journal of Food Products Marketing, 24(4), 441-455. doi: 10.1080/10454446.2017.1311815.

Ecolabel Index (2021). All ecolabels. Available at: http://www.ecolabelindex.com (accessed 18 May 2021).

Eldesouky, A., Mesias, F. J., \& Escribano, M. (2020). Perception of Spanish consumers towards environmentally friendly labelling in food. International Journal of Consumer Studies, 44(1), 64-76. doi: 10.1111/ijcs.12546.

Escofier, B., \& Pagès, J. (2005). Analyses factorielles simples et multiples: objectifs, méthodes et interpretation. Dunod, Paris (France).

Esselunga a casa (2021). Tonno in scatola. Available at: https://www.esselungaacasa.it/ecommerce/nav/auth/supermercato/home.html?utm_campaign=ESS_ao n\&utm_source=sito_esselunga\&utm_term=top_dx\&utm_content=quicklink_esselunga_a_casa\&utm_ medium $=$ internal\&push_login=true\&esseiaOtp=d5537a632bfaa6048e2defe $1 \mathrm{a} 32 \mathrm{da} 627 \mathrm{c} 9 \mathrm{~b} 96620 \# ! / \mathrm{ne}$ gozio/ricerca/TONNO\%20IN\%20SCATOLA?facet=1 (Accessed 10 October 2021).

FAO (2018). The State of World Fisheries and Aquaculture 2018. Meeting the sustainable development goals. FAO, Rome (IT).

FAO (2020). The State of World Fisheries and Aquaculture 2020. Sustainability in action. FAO, Rome (IT). doi: 10.4060/ca9229en (accessed 18 May 2021).

FAO (2021). The nutritional benefits of fish are unique. Available at: http://www.fao.org/inaction/globefish/fishery-information/resource-detail/es/c/338772/ (accessed 18 May 2021).

Feucht, Y., \& Zander, K. (2018). Consumers' preferences for carbon labels and the underlying reasoning. A mixed methods approach in 6 European countries. Journal of Cleaner Production, 178, 740-748. doi: 10.1016/j.jclepro.2017.12.236.

Fliess, B., Lee, H.J., Dubreuil, O.L., \& Agatiello, O. (2007). CSR and trade: informing consumers about social and environmental conditions of globalised production: Part I. OECD Trade Policy Paper No 47 OECD Publishing, Paris (FR).

Follows, S.B., \& Jobber, D. (2000). Environmentally responsible purchase behaviour: a test of a consumer model. European Journal of Marketing, 34(5/6), 723-746. doi: 10.1108/03090560010322009.

García-Martín, M., Torralba, M., Quintas-Soriano, C., Kahl, J., \& Plieninger, T. (2020). Linking food systems and landscape sustainability in the Mediterranean region. Landscape Ecology, 1-17. doi: 10.1007/s10980-020-01168-5.

Greenacre, M., (2007). Correspondence Analysis in Practice. London. Academic Press, Chapman \& Hall/CRC Interdisciplinary Statistics, Boca Raton, FL. 
Grunert, K.G., \& Aachmann, K. (2016), "Consumer reactions to the use of EU quality labels on food products: A review of the literature", Food Control, Vol. 59 January 2016, 178-187. doi: 10.1016/j.foodcont.2015.05.021.

Grunert, K.G., Hieke, S., \&Wills, J. (2014). Sustainability labels on food products: Consumer motivation, understanding and use. Food Policy, 44, 177-189. doi: 10.1016/j.foodpol.2013.12.001.

Grunert, K.G., Sonntag, W.I., \& Glanz-Chanos, V. (2018). Consumer interest in environmental impact, safety, health and animal welfare aspects of modern pig production: Results of a crossnational choice experiment. Meat science, 137, 123-129. doi: 10.1016/j.meatsci.2017.11.022.

Hadjimichael, M., \& Hegland, T.J. (2016). Really sustainable? Inherent risks of eco-labeling in fisheries. Fisheries Research, 174(2016), 129-135. doi: 10.1016/j.fishres.2015.09.012.

Hammarlund, C. (2015). The Big, the Bad, and the Average: Hedonic Prices and Inverse Demand for Baltic Cod. Marine Resource Economics, 30(2), 157-177. doi: 10.1086/679972.

Hartlieb, S., \& Jones, B. (2009). Humanising business through ethical labelling: progress and paradoxes in the UK. Journal of Business Ethics, 88(3), 583-600. doi: 10.1007/s10551-009-0125-x.

Hoek, A.C., Pearson, D., James, S.W., Lawrence, M.A., \& Friel, S. (2017). Healthy and environmentally sustainable food choices: Consumer responses to point-of-purchase actions. Food quality and preference, 58, 94-106. doi: 10.1016/j.foodqual.2016.12.008.

Honkanen, P., \& Ottar Olsen, S. (2009). Environmental and animal welfare issues in food choice: the case of farmed fish. British Food Journal, 111(3), 293-309. doi: 10.1108/00070700910941480.

Honkanen, P., \& Young, J.A. (2015). What determines British consumers' motivation to buy sustainable seafood?. British Food Journal, 117(4), 1289-1302. doi: 10.1108/BFJ-06-2014-0199.

Ipsos (2019). Global attitudes about sustainable fishing and policies to curb overfishing. Available at: https://www.ipsos.com/sites/default/files/ct/news/documents/2020-01/report-sustainable-fishingglobal-advisor-20191202.pdf (accessed 8 October 2021).

Jacobs, S., Sioen, I., Marques, A., \& Verbeke, W. (2018). Consumer response to health and environmental sustainability information regarding seafood consumption. Environmental research, 161, 492-504. doi: 10.1016/j.envres.2017.10.052.

Jaffry, S., Pickering, H., Ghulam, Y., Whitmarsh, D., \& Wattage, P. (2004). Consumer choices for quality and sustainability labelled seafood products in the UK. Food Policy, 29(3), 215-228. doi: 10.1016/j.foodpol.2004.04.001.

Katt, F., \& Meixner, O. (2020). A systematic review of drivers influencing consumer willingness to pay for organic food. Trends in Food Science \& Technology, 100, 374-388. doi: 10.1016/j.tifs.2020.04.029.

Kotler, P. (2011). Reinventing marketing to manage the environmental imperative. Journal of Marketing, 75(4), 132-135. doi: 10.1509/jmkg.75.4.132.

Laroche, M., Bergeron, J., \& Barbaro-Forleo, G. (2001). Targeting consumers who are willing to pay more for environmentally friendly products. Journal of Consumer Marketing, 18(6), 503-520. doi: 10.1108/EUM0000000006155.

Leach, A.M., Emery, K.A., Gephart, J., Davis, K.F., Erisman, J.W., Leip, A., Pace, M.L., D’Odorico, P., Carr, J., Noll, L.C., \& Castner, E. (2016). Environmental impact food labels combining carbon, nitrogen, and water footprints. Food Policy, 61, 213-223. doi: 10.1016/j.foodpol.2016.03.006.

Lee, K. (2014). Predictors of sustainable consumption among young educated consumers in Hong Kong. Journal of International Consumer Marketing, 26(3), 217-238. doi: 10.1080/08961530.2014.900249.

Li, N., Wu, X., Zhuang, W., Xia, L., Chen, Y., Wu, C., Rao, Z., Du, L., Zhao, R., Yi, M., Wan Q., \& Zhou, Y. (2020). Fish consumption and multiple health outcomes: Umbrella review. Trends in Food Science \& Technology, 99, 273-283. doi: 10.1016/j.tifs.2020.02.033. 
Li, X., Tan H., \& Rackes, A. (2015). Carbon footprint analysis of student behavior for a sustainable University campus in China. Journal of Cleaner Production, 106, 97-108. doi: 10.1016/j.jclepro.2014.11.084.

Likert, R. (1932). A technique for the measurement of attitudes. Archives of psychology. New York (USA).

Loureiro, M.L., \& Lotade, J. (2005). Do fair trade and eco-labels in coffee wake up the consumer conscience? Ecological Economics, 53(1), 129-138. doi: 10.1016/j.ecolecon.2004.11.002.

Maesano, G., Di Vita, G., Chinnici, G., Pappalardo, G., \& D'Amico, M. (2020). The Role of Credence Attributes in Consumer Choices of Sustainable Fish Products: A Review. Sustainability, 12(23), 10008. doi: 10.3390/su122310008.

Mäkiniemi, J.P., Pirttilä-Backman, A.M., \& Pieri, M. (2011). Ethical and unethical food. Social representations among Finnish, Danish and Italian students. Appetite, 56(2), 495-502. doi: 10.1016/j.appet.2011.01.023.

Maxwell, S.M., Hazen, E.L., Lewison R.L., Dunn, D.C., Bailey, H., Bograd, S.J., Briscoe, D.K., Fossette, S., Hobday, A.J., Bennett, M., Benson, S., Caldwell, M.R., Costa, D.P., Dewar, H., Eguchi, T., Hazen, L., Kohin, S., Sippel, T., \& Crowder, L.B. (2015). Dynamic ocean management: defining and conceptualizing real-time management of the ocean". Marine Policy, 58, 42-50. doi: 10.1016/j.marpol.2015.03.014.

Mori Junior, R., Franks, D.M., \& Ali, S.H. (2016). Sustainability certification schemes: evaluating their effectiveness and adaptability. Corporate Governance, 16(3), 579-592. doi: 10.1108/CG-032016-0066.

OECD (2009). Consumer education. Policy recommendations of the OECD's committee on Consumer Policy. OECD Publishing, Paris (FR).

OECD (2021). Fisheries and Aquaculture in Italy. January 2021. Available at: https://www.oecd.org/agriculture/topics/fisheries-and-aquaculture/documents/report_cn_fish_ita.pdf (accessed 8 October 2021).

Oliwa, B. (2021). The Concept of the Triple Bottom Line as a Link Between Sustainability and CSR. In Adapting and Mitigating Environmental, Social, and Governance Risk in Business, 1-25. IGI Global. doi: 10.4018/978-1-7998-6788-3.ch001.

Padel, S., \& Foster, C. (2005). Exploring the gap between attitudes and behaviour: Understanding why consumers buy or do not buy organic food. British Food Journal, 107(8), 606-625. doi: 10.1108/00070700510611002.

Panico, T., Del Giudice, T., Amato, M., Caracciolo, F., \& Verneau, F. (2014). Evaluating Italian attitude and behaviour toward Fair Trade products. Rivista di Economia Agraria/Italian Review of Agricultural Economics, 69(2-3), 211-225. http://dx.doi.org/10.13128/REA-16923.

Petrescu, D.C., Vermeir, I., \& Petrescu-Mag, R.M. (2020). Consumer understanding of food quality, healthiness, and environmental impact: A cross-national perspective. International journal of environmental research and public health, 17(1), 169. doi: 10.3390/ijerph17010169.

Porter, M., \& Van der Linde, C. (1995). Green and competitive: ending the stalemate. The Dynamics of the eco-efficient economy: environmental regulation and competitive advantage, 33 .

Roheim, C.A., Asche, F., \& Santos, J.I. (2011). The elusive price premium for eco-labelled products: evidence from seafood in the UK market. Journal of Agricultural Economics, 62(3), 655-668. doi: 10.1111/j.1477-9552.2011.00299.x.

Roheim, C.A., Gardiner, L., \& Asche, F. (2007). Value of brands and other attributes: Hedonic analysis of retail frozen fish in the UK. Marine Resource Economics, 22(3), 239-253. doi: $10.1086 / 679972$. 
Sammer, K., \&Wüstenhagen, R. (2006). The influence of eco-labelling on consumer behavior. Results of a discrete choice analysis for washing machines. Business Strategy and the Environment, 15(3), 185-199. doi: 10.1002/bse.522.

Savelli, E., Murmura, F., Liberatore, L., Casolani, \& N., Bravi, L. (2017). Consumer attitude and behaviour towards food quality among the young ones: empirical evidences from a survey. Total Quality Management \& Business Excellence, 30(1-2), 169-183. doi: 10.1080/14783363.2017.1300055.

Schäufele, I., \& Hamm, U. (2017). Consumers' perceptions, preferences and willingness-to-pay for wine with sustainability characteristics: A review. Journal of Cleaner Production, 47, 379-394. doi: 10.1016/j.jclepro.2017.01.118.

Shaw, D., \& Clarke, I. (1999). Belief formation in ethical consumer groups: an exploratory study. Marketing intelligence \& planning. doi: 10.1108/02634509910260968.

Sidali, K.L., Spiller, A., \& von Meyer-Höfer, M. (2016). Consumer expectations regarding sustainable food: Insights from developed and emerging markets. International Food and Agribusiness Management Review, 19(3), 141-170.

Sidiropoulos, E. (2018). The personal context of student learning for sustainability: Results of a multiUniversity research study. Journal of Cleaner Production, 181, 537-554. doi: 10.1016/j.jclepro.2018.01.083.

Tate, W.L., Ellram, L.M., \& Kirchoff, J. F. (2010). Corporate social responsibility reports: a thematic analysis related to supply chain management. Journal of supply chain management, 46(1), 19-44. doi: 10.1111/j.1745-493X.2009.03184.x.

Taufique, K.M.R., Polonsky, M.J., Vocino, A., \& Siwar, C. (2019). Measuring consumer understanding and perception of eco-labelling: Item selection and scale validation. International journal of consumer studies, 43(3), 298-314. doi: 10.1111/ijcs.12510.

Teisl, M.F., Roe, B., \& Hicks, R.L. (2002). Can eco-labels tune a market? Evidence from dolphin-safe labelling. Journal of Environmental Economics and Management, 43(3), 339-359. doi: 10.1006/jeem.2000.1186.

Thilsted, S.H., Thorne-Lyman, A., Webb, P., Bogard, J.R., Subasinghe, R., Phillips, M.J., \& Allison, E.H. (2016). Sustaining healthy diets: The role of capture fisheries and aquaculture for improving nutrition in the post-2015 era. Food Policy, 61, 126-131. doi: 10.1016/j.foodpol.2016.02.005.

Tully, S.M., \& Winer, R.S. (2014). The role of the beneficiary in willingness to pay for socially responsible products: a meta-analysis. Journal of Retailing, 90(2), 255-274. doi: 10.1016/j.jretai.2014.03.004.

Van Loo, E.J., Caputo, V., Nayga Jr, R.M., \& Verbeke, W. (2014). Consumers' valuation of sustainability labels on meat. Food Policy, 49, 137-150. doi: 10.1016/j.foodpol.2014.07.002.

Van Loo, E.J., Caputo, V., Nayga Jr, R.M., Seo, H.S., Zhang, B., \& Verbeke, W. (2015). Sustainability labels on coffee: Consumer preferences, willingness-to-pay and visual attention to attributes. Ecological Economics, 118, 215-225. doi: 10.1016/j.ecolecon.2015.07.011.

Varese, E., Pellicelli, A.C., \& Bollani, L. (2022 in press). Are consumers really informed on Corporate Social Responsibility labels for fishery products? Results of an Italian case study. In: 2021 International Conference on Comprehensible Science Proceeding, Eilat, Israel, June 18-20, 2021, Springer.

Vecchio, R., \& Annunziata, A. (2013). Consumers' attitudes towards sustainable food: a cluster analysis of Italian University students. New Medit, 12(2), 47-56.

Velarde, A., Fàbrega, E., Blanco-Penedo, I., \& Dalmau, A. (2015). Animal welfare towards sustainability in pork meat production. Meat Science, 109, 13-17. doi: 10.1016/j.meatsci.2015.05.010.

Verbeke, W., Vanhonacker, F., Sioen, I., Van Camp, J., \& De Henauw, S. (2007). Perceived importance of sustainability and ethics related to fish: A consumer behavior perspective. AMBIO: A 
Journal of the Human Environment, 36(7), 580-585. doi: 10.1579/00447447(2007)36[580:PIOSAE]2.0.CO;2.

Vermeir, I., \& Verbeke, W. (2006). Sustainable food consumption: Exploring the consumer "attitudebehavioral intention" gap. Journal of Agricultural and Environmental Ethics, 19(2), 169-194. doi: 10.1007/s10806-005-5485-3.

Vermeir, I., \& Verbeke, W. (2008). Sustainable food consumption among young adults in Belgium: Theory of planned behaviour and the role of confidence and values. Ecological Economics, 64(3), 542-553. doi: 10.1016/j.ecolecon.2007.03.007.

Vlaeminck, P., Vandoren, J., Vranken, L., Squicciarini, M., \& Swinnen, J. (2016). Consumers' willingness to pay for fair trade chocolate. In The Economics of Chocolate (edited by M.P. Squicciarini and J. Swinnen) Oxford University Press, Oxford (UK), 180-193.

Yaktine, A.L., \& Nesheim, M.C. (Eds.). (2007). Seafood choices: balancing benefits and risks. The National Academies Press, Washington, D.C. (USA).

Zadek, S. (2007). The path to corporate responsibility. In Corporate ethics and corporate governance. Springer, Berlin, Heidelberg (DE), 159-172. doi: 10.1007/978-3-540-70818-6_13.

Zadek, S., Lingayah, S., \& Forstater, M. (1998). Social labels: Tools for ethical trade. New Economics Foundation, London (UK).

Zander, K., Padel, S., \&Zanoli, R. (2015). EU organic logo and its perception by consumers. British Food Journal, 117(5), 1506-1526. doi: 10.1108/BFJ-08-2014-0298.

Zeng, S. X., Meng, X.H., Yin, H.T., Tam, C.M., \& Sun, L. (2010). Impact of cleaner production on business performance. Journal of Cleaner Production, 18(10-11), 975-983. doi: 10.1016/j.jclepro.2010.02.019. 